\title{
Fossils from the Middle Jurassic Wanakah Formation near Delta in Western Colorado
}

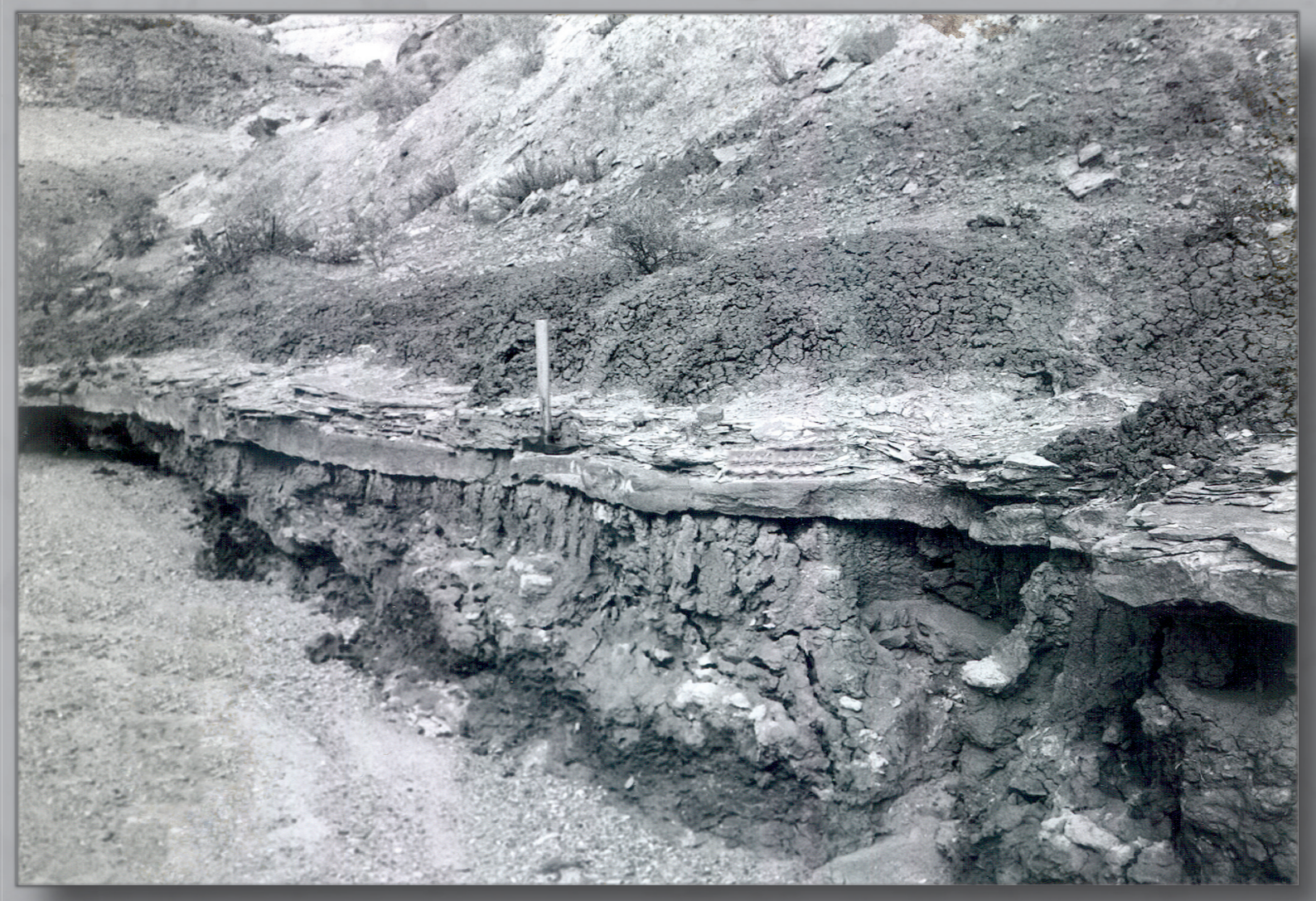

Scientific Investigations Report 2006-5105 


\section{Fossils from the Middle Jurassic Wanakah Formation near Delta in Western Colorado}

By R.B. O'Sullivan, M.A. Carey, and S.C. Good

Scientific Investigations Report 2006-5105 


\section{U.S. Department of the Interior DIRK KEMPTHORNE, Secretary \\ U.S. Geological Survey \\ P. Patrick Leahy, Acting Director}

\section{U.S. Geological Survey, Reston, Virginia: 2006}

Posted online August 2006

This publication is only available online at http://pubs.usgs.gov/sir/2006/5105/

For more information on the USGS - the Federal source for science about the Earth, its natural and living resources, natural hazards, and the environment:

World Wide Web: http://www.usgs.gov

Telephone: 1-888-ASK-USGS

Any use of trade, product, or firm names is for descriptive purposes only and does not imply endorsement by the U.S. Government.

Although this report is in the public domain, permission must be secured from the individual copyright owners to reproduce any copyrighted materials contained within this report.

Suggested citation:

O'Sullivan, R.B., Carey, M.A., Good, S.C., 2006, Fossils from the Middle Jurassic Wanakah Formation near Delta in western Colorado: U.S. Geological Survey Scientific Investigations Report 2006-5105, 6 p. 


\section{Contents}

Abstract
Introduction
Previous Work
Present Investigation
References Cited

\section{Figures}

1. Maps showing distribution of Wanakah Formation and the Delta-Bridgeport area.........2

2. Nomenclature chart of Middle and Upper Jurassic rocks in the San Rafael Swell and

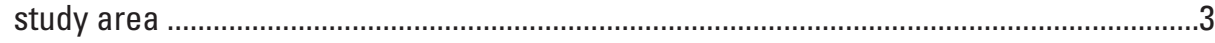

3. Photographs of fossil bed and some fossil forms ........................................................ 


\title{
Fossils from the Middle Jurassic Wanakah Formation near Delta in Western Colorado
}

\author{
By R.B. O'Sullivan, M.A. Carey, and S.C. Good'
}

\begin{abstract}
The Middle Jurassic Wanakah Formation averages about $30 \mathrm{~m}$ in thickness in Colorado. Fossils are sparse and include fish, ostracodes, and trace fossils. A thin $(0.03-0.45 \mathrm{~m})$ fossil bed near the middle of the formation extends for some $48 \mathrm{~km}$ along the northeast flank of the Uncompahgre Plateau near Delta. The fossil bed at one locality contains one pelecypod identified possibly as Modiolus cf. M. subimbricatus (Meek), as well as other specimens too poorly preserved for identification. Previously, Mytilus was found in the same fossil bed at another locality by C.N. Holmes. The Wanakah Formation is primarily of terrestrial origin, but the fossil bed represents a shallow-marine incursion.
\end{abstract}

\section{Introduction}

The Middle Jurassic Wanakah Formation is widespread in Colorado and the adjacent States of Utah, Arizona, and New Mexico (fig. 1A). Only a few fossils have been reported from the formation, so its origin is still somewhat speculative. Near Delta in western Colorado, the recovery of a single bivalve mollusk, together with associated fossils, contributes to understanding the local depositional environments of the formation.

The Wanakah Formation was named for strata that overlie the Middle Jurassic Entrada Sandstone and underlie the Upper Jurassic Morrison Formation. The name is derived from the Wanakah base and precious metals mine $1.6 \mathrm{~km}$ north of Ouray and $85 \mathrm{~km}$ south of Delta (Burbank, 1930). The Wanakah has been mapped in the Grand Junction area, just to the north of the study area (Scott and others, 2001), and has been traced from Bridgeport (fig. $1 B$ ) southward to Ouray (fig. 1A; O'Sullivan, 2004). The formation consists of a thin basal limestone member overlain by a thicker and more extensive sequence of sandstone and siltstone. The basal limestone member is termed Pony Express in Colorado and Todilto in New Mexico and Arizona.

${ }^{1}$ Department of Geology and Astronomy, West Chester University, West Chester, Pa., 19383
Near Ouray, the Wanakah Formation is $27-38 \mathrm{~m}$ thick and consists of three units-in ascending order, the Pony Express Limestone Member, the Bilk Creek Sandstone Member, and the beds at Sawpit. The Pony Express Limestone Member is a dark-gray limestone generally 0-6 m thick within Colorado. However, near Ouray, where the upper part locally contains a thick lens of gypsum, the member is about $18 \mathrm{~m}$ thick. North of Ouray the Pony Express dips northward beneath younger rocks, and where the Wanakah reappears at the surface along Dry Creek $20 \mathrm{~km}$ southeast of Olathe (fig. 1B), the Pony Express Limestone Member is absent (see O'Sullivan, 2004). The Bilk Creek Sandstone Member, 4.5-9 $\mathrm{m}$ thick, is a fine-grained, flat-bedded sandstone capped by a distinctive carnelian sandstone marker bed. This marker bed, generally $0.3-0.6 \mathrm{~m}$ thick, is a poorly sorted, fine-grained sandstone containing sparse to abundant, rounded, coarse quartz grains. The beds at Sawpit at the top of the formation are mostly interbedded red sandstone and siltstone in units that are generally less than $0.9 \mathrm{~m}$ thick.

\section{Previous Work}

Holmes (1960, fig. 30), in his study of Jurassic stratigraphy in Colorado, assigned the strata above the Entrada Sandstone to the Summerville Formation, the type section of which is in Utah about $215 \mathrm{~km}$ west of Delta. In our study area (fig. 1), however, we consider the name Wanakah Formation to take precedence, following the definition of Burbank (1930, p. 171-177) for exposures near Ouray (fig. 1A). Furthermore, regional correlations, shown in figure 2, indicate the Summerville-which is separated from the Entrada by the Curtis Formation (a marine sandstone about $61 \mathrm{~m}$ thick) at the type locality-to be younger than the Wanakah.

Some of the strata we now recognize as Wanakah Formation were incorrectly assigned to the basal Morrison Formation in the area extending from Bridgeport (fig. $1 B$ ) west to Dewey Bridge in Utah by O'Sullivan and Pipiringos (1983). However, the stratigraphic relationships were clarified in a more recent report by O'Sullivan (2004).

The few fossils reported for the Wanakah Formation are mostly from the basal limestone member- the Pony Express in Colorado and the Todilto in New Mexico and Arizona. 

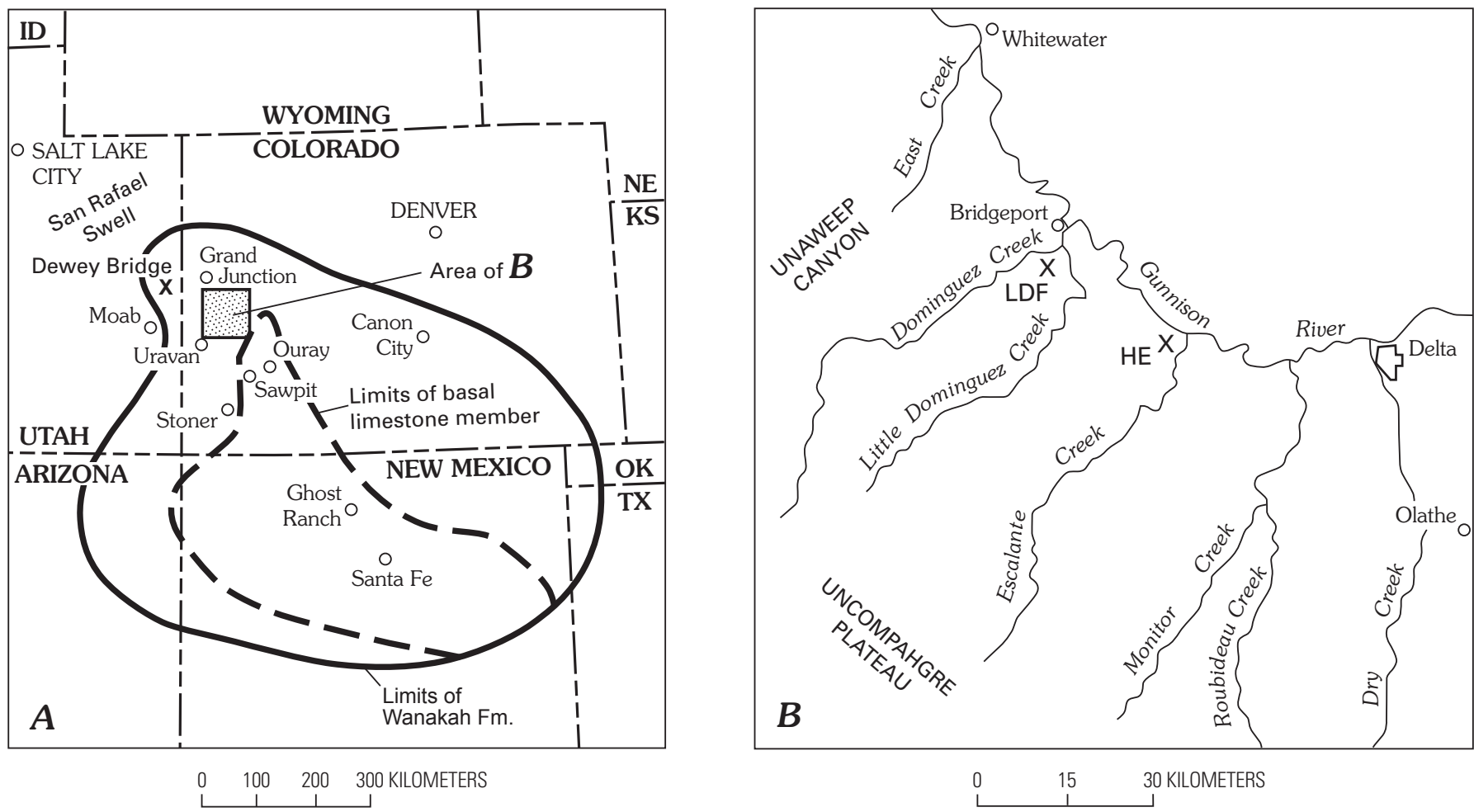

Figure 1. Distribution of Wanakah Formation and the Delta-Bridgeport area. $A$, Distribution of Wanakah Formation, modified from Schaeffer and Patterson (1984, fig. 1); limits of the basal limestone member of the Wanakah Formation from Ridgley (1989, fig. 10). $B$, Map of Delta-Uncompahgre Plateau area. LDF, Little Dominguez fossil locality; HE, Escalante Creek fossil locality of Holmes (1960).

They include fish, ostracodes, and aquatic insects described by Schaeffer and Patterson (1984) and Lucas and others (1985). Lucas and others (1985, p. 220-227) and Kirkland and others (1995, p. 33) concluded that the basal limestone of the Wanakah is of saline lake origin, whereas Harshbarger and others (1957, p. 46) interpreted the Todilto Limestone Member to be of marine origin. Work on sulfur-isotope compositions by Adler (1974, p. 630) and whole-rock carbon-, oxygen-, and sulfur-isotope studies by Ridgley and Goldhaber (1983, p. 414) suggested to them a marine rather than a lacustrine origin for the basal limestone.

The following fossils have been reported above the Pony Express and Todilto Limestone Members of the Wanakah Formation:

1. Lockley (1991, p. 59-65) documented abundant dinosaur footprints at a locality north of Moab, Utah.

2. Steele $(1985$, p. 9,11$)$ reported ostracodes (no distinction as to marine or freshwater forms) from the Bilk Creek Sandstone Member near Sawpit and Stoner (fig. $1 A$ ) in southwest Colorado and from the upper part of the Wanakah (beds at Sawpit) at an unspecified locality in the area between Uravan and Stoner (fig. 1A).

3. Trace fossils and the nonmarine mollusk Vetulonia were reported from the upper member of the Wanakah, above the Todilto Limestone Member, near Ghost Ranch in northwestern New Mexico (fig. 1A), and were considered to be of shallow-lacustrine origin by Ridgley (1989).

4. Fish and plants were described by Schultze and Enciso (1983) from strata assigned to the Wanakah Formation by Schaeffer and Patterson (1984, p. 10-12) near Canon City in eastern Colorado. Lucas and others (1985, fig. 7) regarded the strata near Canon City as being part of the lacustrine facies of the Todilto Limestone Member.

\section{Present Investigation}

South and west of Delta (fig. 1B), the Wanakah Formation crops out in several places on the northeast side of the Uncompahgre Plateau, where the ground surface rises from an elevation of 1,443 $\mathrm{m}$ at a benchmark near Bridgeport to more than 2,987 m at the crest of the plateau. Deep canyons, trending northeast, reveal Cretaceous and Upper Jurassic rocks including the Wanakah Formation as well as underlying formations. These canyons include Little Dominguez, Escalante, Roubideau, and Dry Creeks, which flow into the Gunnison River south and east of Bridgeport (fig. 1B). 


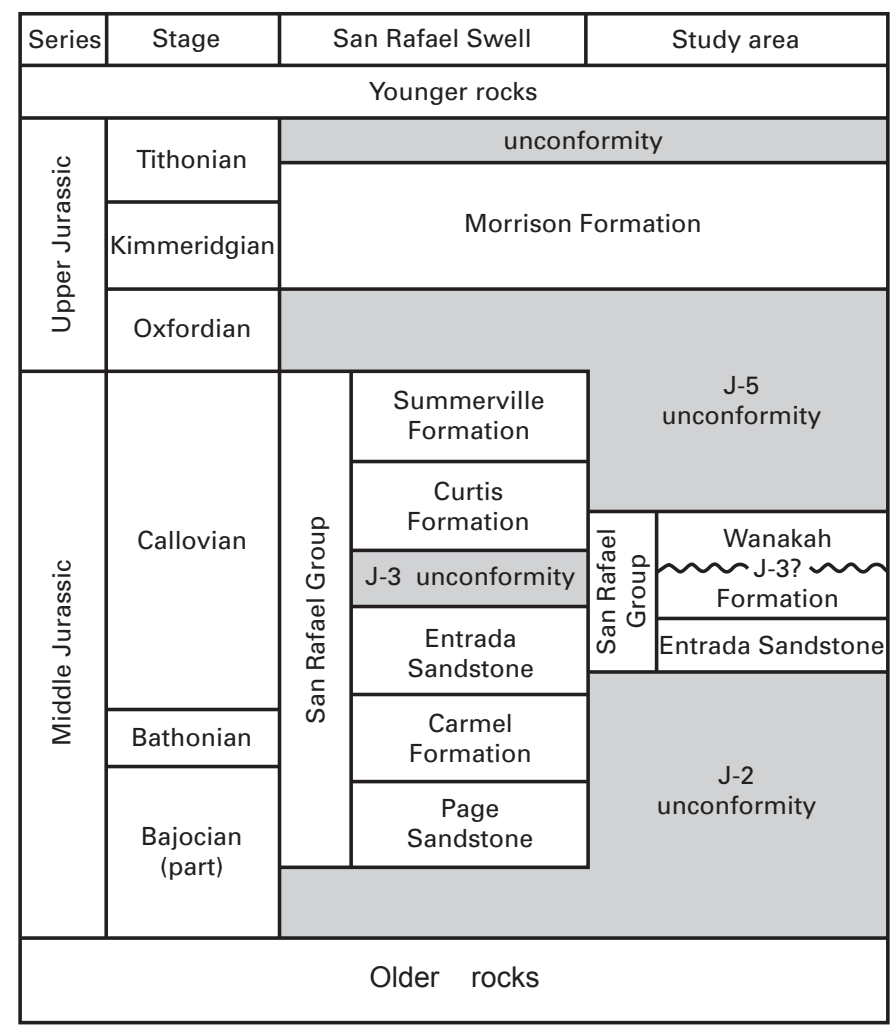

Figure 2. Nomenclature of Middle and Upper Jurassic rocks in the San Rafael Swell and study area. Labeled unconformities discussed in Pipiringos and O'Sullivan (1978).

During our study, a fossil locality was found, by O'Sullivan, along Little Dominguez Creek about $3.2 \mathrm{~km}$ south of Bridgeport in a unit near the middle of the Wanakah referred to as the fossil bed. The fossil collection consisted of a single mollusk with associated poorly preserved and as-yet-unidentified fossils. Another pelecypod locality, described previously by Holmes (1960), is in the same bed along Escalante Creek (fig. $1 B$ ). The fossil bed is a thin gray sandstone extending from Bridgeport southeast to Dry Creek; it is overlain by a thin red claystone throughout the area.

The following stratigraphic section shows the thickness and lithologies of the Wanakah Formation at the fossil locality (section measured along Little Dominguez Creek $3.2 \mathrm{~km}$ south of Bridgeport, Colo., in NE1/4NE1/4SE1/4 sec. 30, T. 14 S., R. 98 W.; Triangle Mesa 7.5-minute quadrangle, 1969):

Thickness (meters)

Jurassic System:

Upper Jurassic Series:

Morrison Formation:

Tidwell Member (part):

Bed A:

12. Sandstone, yellowish-gray, flat-bedded and ripple-marked; coarse to very coarse grains; forms ledge; base is $\mathrm{J}-5$

unconformity...

Thickness of bed A ........................... 2.16

Middle Jurassic Series:

Wanakah Formation:

Beds at Sawpit:

11. Siltstone; forms a slope; poorly exposed beneath a hard layer of rubble; reddish-tan and olive-drab siltstones occur at various levels; a 0.15-m-thick, yellowish-gray, very fine grained sandstone makes a slight ledge at base of unit; sparse, thin, dovegray limestone nodules are present ........ 7.31

10. Siltstone, reddish-brown; forms a slope; poorly exposed beneath a hard veneer of rubble; red siltstone exposed at several horizons

9. Claystone, reddish-brown; flaky, silty ....0.24

8. Fossil bed; sandstone, gray, fine-grained; forms square-faced ledge

7. Siltstone, reddish-brown; forms small slope.

6. Sandstone, gray, flat-bedded; forms conspicuous ledge that overhangs underlying units.

5. Sandstone, reddish-tan, mottled and streaked gray; sparse medium-sized quartz grains; thin reddish-brown siltstone layers make deep reentrants $4.05 \mathrm{~m}$ above base and at top of unit

Thickness of beds at Sawpit. 18.29

Bilk Creek Sandstone Member:

4. Carnelian sandstone marker bed; sandstone, moderate-orange-pink, crossbedded; abundant rounded, medium-size quartz grains; forms ledge that overhangs underlying unit

3. Siltstone, reddish-brown, mottled gray; sandy; forms conspicuous reentrant beneath unit 4

2. Sandstone, reddish-tan, mottled gray; sparse medium-size grains; forms gentle slope.

1. Sandstone, gray; lower $0.3 \mathrm{~m}$ is reddishtan, flat-bedded; conspicuous nick at base

Thickness Bilk Creek Sandstone

Member $\underline{6.53}$

Total thickness Wanakah

Formation 24.82

Entrada Sandstone (not described) 
The single bivalve mollusk collected at the Little Dominguez Creek locality was from the top of the fossil bed (unit 8 of the measured section). Although poorly preserved (fig. $3 B-C$ ), it can most reliably be identified, by Good, as Modiolus cf. M. subimbricatus (Meek). The specimen has a length of $17 \mathrm{~mm}$, a growth axis of $19 \mathrm{~mm}$, and a width of 11 $\mathrm{mm}$. Modiolus is common in Jurassic rocks in Utah (Imlay, 1964) and is indicative of a shallow-marine environment. We noted possible sponge spicules at several localities in the fossil bed, and we found other fossils of uncertain classification (fig. $3 D-E$ ) at several different places in the fossil bed.

Pelecypod fossils collected near the mouth of Escalante Creek by Holmes (1960, p. 107) were examined by J.B. Reeside, Jr. (U.S. Geological Survey) and identified as an unnamed species of Mytilus of marine origin. Small calcareous tubes possibly formed by serpulid worms are also present at the same locality (Holmes, 1960, p. 107). A comparison of the section measured by Holmes (1960, fig. 30) with sections measured by O'Sullivan (2004) along Escalante Creek indicates that the fossil horizon described by Holmes is the fossil bed of the Wanakah Formation.

\section{Conclusion}

The Wanakah Formation is probably mostly of terrestrial origin. The red in the beds at Sawpit suggests a subaerial environment of deposition, but trace fossils at localities in New Mexico indicate that some beds are of lacustrine origin. The flat, thin, uniform bedding and lack of scour surfaces may reflect deposition in quiet waters. Some beds are widely distributed; the fossil bed, for example, is found from Bridgeport to Dry Creek, a distance of some 48 $\mathrm{km}$, and the carnelian sandstone marker bed can be traced from Little Dominguez Creek to Ouray, a distance of 113 $\mathrm{km}$. The various bedding features suggest a deltaic environment of deposition, as was interpreted by Wright (1959, p. 63 ), and the fossil bed represents a local incursion of the sea. During our investigation, the fossil bed was inspected only in a reconnaissance fashion, so future, more careful examinations of the fossil bed may reveal new forms that will add to a better understanding of the conditions of deposition of the Wanakah Formation.

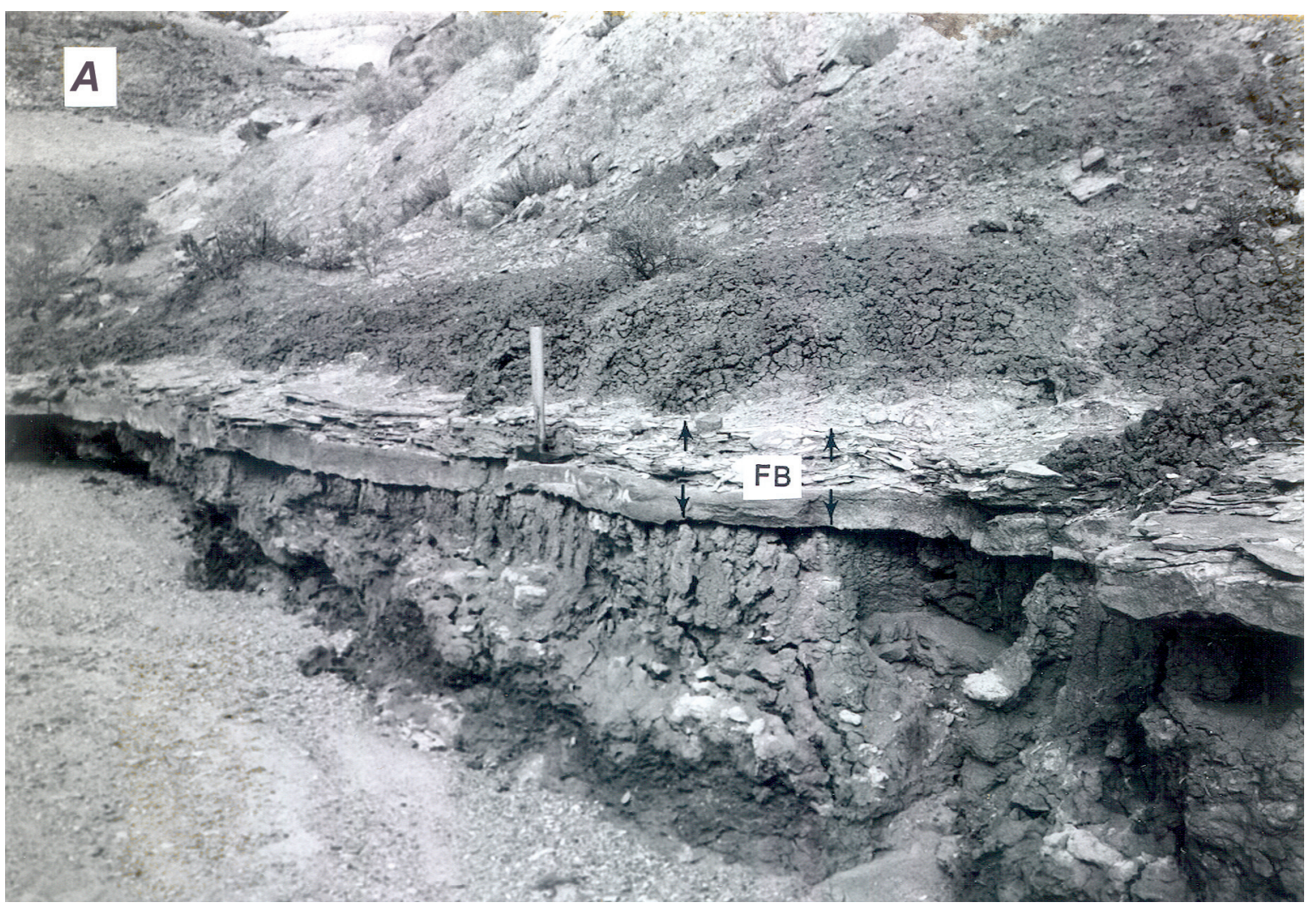

Figure 3 (above and following page). Fossil bed and some fossil forms. A, Fossil bed (FB) on Escalante Creek; arrows indicate top and bottom of fossil bed. Dark band above fossil bed is claystone. View is to northwest in SE1/4 sec. 30, T. 15 S., R. 97 W. Length of hammer handle is $28 \mathrm{~cm}$ for scale. $B$, Lateral view of right valve of Modiolus from the Little Dominguez fossil locality. $C$, Posterior view of Modiolus. $D$, Shell impression from fossil bed on Little Dominguez Creek. E, Fragment resembling a bryozoan matrix from fossil bed at Bridgeport. Scales in millimeters. 

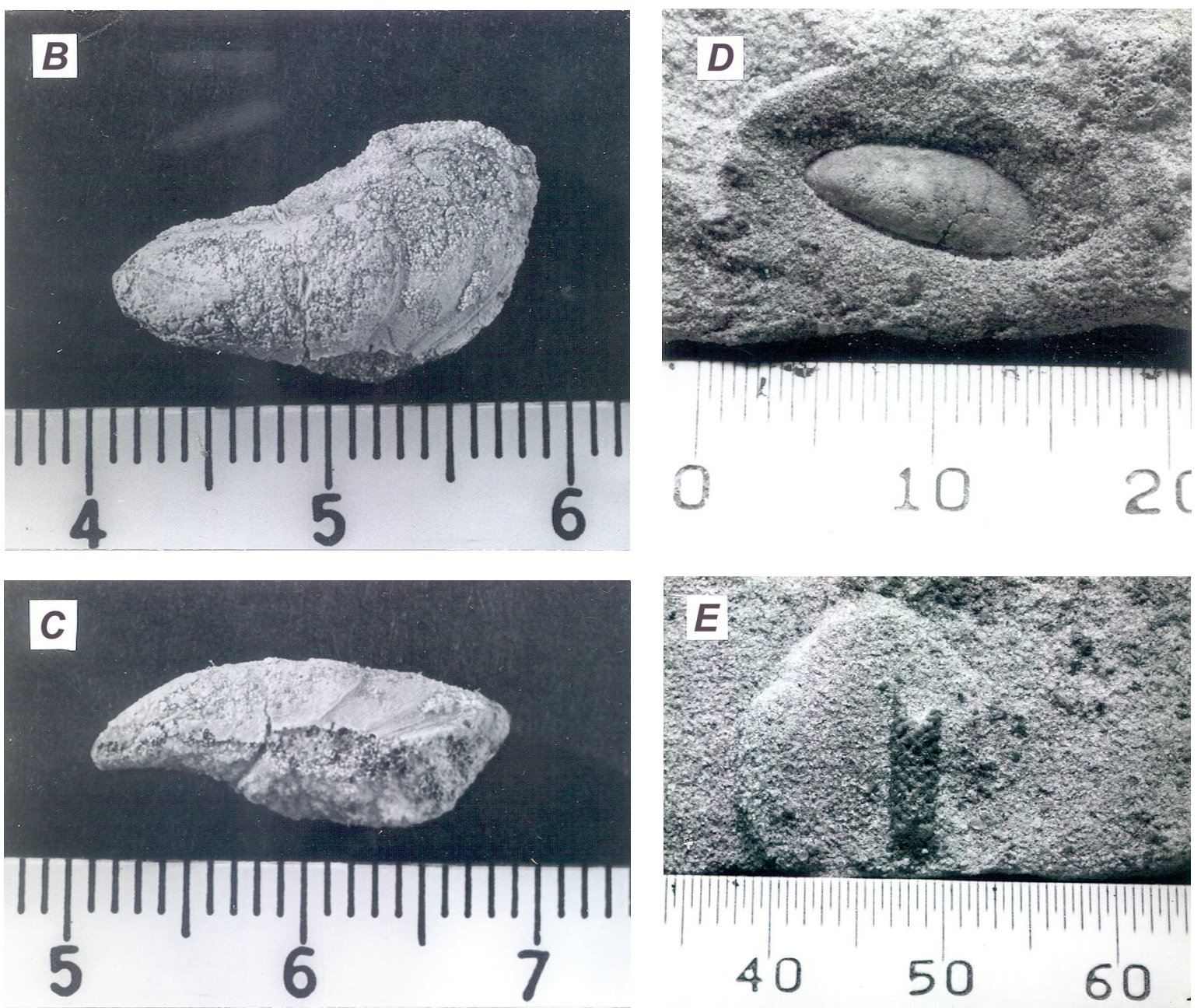

\section{References Cited}

Adler, H.H., 1974, Sulfur-isotope composition of Jurassic and Triassic marine sulfates of the United States: Geological Society of America Abstracts with Programs, v. 6, no. 7, p. 630.

Burbank, W.S., 1930, Revision of geologic structure and stratigraphy in the Ouray district of Colorado and its bearing on ore deposition: Colorado Scientific Society Proceedings, v. 12 , p. 151-232.

Harshbarger, J.W., Repenning, C.A., and Irwin, J.H., 1957, Stratigraphy of the uppermost Triassic and Jurassic rocks of the Navajo country: U.S. Geological Survey Professional Paper 291, $74 \mathrm{p}$.

Holmes, C.N., 1960, Jurassic history and stratigraphy of Colorado: Salt Lake City, Utah, University of Utah Ph. D. thesis, $396 \mathrm{p}$.

Imlay, R.W., 1964, Marine Jurassic pelecypods from central and southern Utah: U.S. Geological Survey Professional Paper 483-C, p. C1-C40.
Kirkland, D.W., Denison, R.E., and Evans, R., 1995, Middle Jurassic Todilto Formation of northern New Mexico and southwestern Colorado-Marine or nonmarine?: New Mexico Bureau of Mines and Mineral Resources Bulletin 147, $37 \mathrm{p}$.

Lockley, M.G., 1991, The Moab megatracksite-A preliminary description and discussion of millions of Middle Jurassic tracks in eastern Utah: Grand Junction Geological Society Guidebook for Dinosaur Quarries and Tracksites Tour, western Colorado and eastern Utah, p. 59-65.

Lucas, S.C., Kietzke, K.K., and Hunt, A.P., 1985, The Jurassic System in east-central New Mexico: Socorro, N. Mex., New Mexico Geological Society, Guidebook 36, p. 213-242.

O’Sullivan, R.B., 2004, Correlation of Middle Jurassic San Rafael Group and related rocks from Bridgeport to Ouray in western Colorado: U.S. Geological Survey Scientific Investigations Map 2849, 1 sheet.

O’Sullivan, R.B., and Pipiringos, G.N., 1983, Stratigraphic sections of Middle Jurassic Entrada Sandstone and related rocks from Dewey Bridge, Utah, to Bridgeport, Colorado: 
U.S. Geological Survey Oil and Gas Investigations Chart OC-122, 1 sheet.

Pipiringos, G.N., and O'Sullivan, R.B., 1978, Principal unconformities in Triassic and Jurassic rocks, Western Interior United States-A preliminary survey: U.S. Geological Survey Professional Paper 1035-A, p. A1-A29.

Ridgley, J.L., 1989, Trace fossils and mollusks from the upper member of the Wanakah Formation, Chama basin, New Mexico-Evidence for a lacustrine origin: U.S. Geological Survey Bulletin 1808, Chapter C, p. C1-C16.

Ridgley, J.L., and Goldhaber, Martin, 1983, Isotopic evidence for a marine origin of the Todilto Limestone, north-central New Mexico: Geological Society of America Abstracts with Programs, v. 15 , no. 5, p. 414.

Schaeffer, Bobb, and Patterson, Colin, 1984, Jurassic fishes from the western United States, with comments on Jurassic fish distribution: American Museum of Natural History Novitates Number 2796, 86 p.
Schultze, Hans-Peter, and Enciso, Gonzalo, 1983, Middle Jurassic age of the fish-bearing horizon in the Canon City embayment, Colorado: Journal of Paleontology, v. 57, no. 5, p. 1053-1060.

Scott, R.B., Harding, A.E., Hood, W.C., Cole, R.D., Livaccari, R.F., Johnson, J.B., Shroba, R.R., and Dickerson, R.P., 2001, Geologic map of Colorado National Monument and adjacent areas, Mesa County, Colorado: U.S. Geological Survey Geologic Investigations Series I-2740, scale 1:24,000, 40-p. pamphlet.

Steele, B.A., 1985, Preliminary report on and measured sections of the Middle Jurassic Entrada Sandstone and Wanakah Formation near Placerville, southwestern Colorado: U.S. Geological Survey Open-File Report 85-446, 55 p.

Wright, J.C., 1959, San Rafael (Entrada) studies, in Geologic investigations of radioactive deposits-Semiannual progress report for December 1, 1958 to May 31, 1959: U.S. Atomic Energy Commission, Trace Element Investigation TEI-751, p. 61-66. 